\title{
BIOMEDICAL WASTE MANAGEMENT- CURRENT PRACTICES AND FUTURE PROSPECTIVE IN URBAN AREA
}

\author{
Ranjith Gowda A S, Rekha. B, Shradha Satish Wantamutte, Vikas Kumar P \\ Department Of Civil Engineering \\ Dayananda Sagar College Of Engineering, Bangalore
}

\begin{abstract}
Biomedical waste has become a serious health hazard in many countries including India. The safe and sustainable management of biomedical waste (BMW) is social and legal responsibility of all people supporting and financing health-care activities. Effective BMW management (BMWM) is mandatory for healthy humans and cleaner environment. This article reviews about various attempt to study the classification \& various management pratices by countries. The new rules are meant to improve the segregation, transportation, and disposal methods, to decrease environmental pollution so as to change the dynamic of BMW disposal and treatment in India. For effective disposal of BMWM, there should be a collective teamwork with committed government support in terms of finance and infrastructure development, dedicated health-care workers and health-care facilities, continuous monitoring of BMW practices, tough legislature, and strong regulatory bodies. The basic principle of BMWM is segregation at source and waste reduction. Besides, a lot of research and development need to be in the field of developing environmental friendly medical devices and BMW disposal systems for a greener and cleaner environment.
\end{abstract}

Keywords_- Biomedical waste, Infectious_disease, Segregate.

\section{INTRODUCTION}

Bio-medical waste means "any solid and/or liquid waste including its container and any intermediate product, which is generated during the diagnosis, treatment or immunization of human beings or animals or research activities pertaining thereto or in the production or testing of biological or in health camps. All human activities produce waste. We all know that such waste may be dangerous and needs safe disposal. Industrial waste, sewage and agricultural waste pollute water, soil and air. It can also be dangerous to human beings and environment. Similarly, hospitals and other health care facilities generate lots of waste which can transmit infections, particularly HIV, Hepatitis B \& C and Tetanus, to the people who handle it or come in contact with it.

Bio Medical waste consists of
- Human anatomical waste like tissues, organs and body parts.

- Animal wastes generated during research from veterinary hospitals.

- Microbiology and biotechnology wastes.

- Waste sharps like hypodermic needles, syringes, scalpels and broken glass

- $\quad$ Discarded medicines and cytotoxic drugs.

- Soiled waste such as dressing, bandages, plaster casts, material contaminated with blood, tubes and catheters.

- $\quad$ Liquid waste from any of the infected areas.

- Incineration ash and other chemical wastes.

Effect on humans

Disposal of this waste is an environmental concern, as many medical wastes are classified as infectious or biohazardous and could potentially lead to the spread of infectious disease. The most common danger for humans is the infection which also affects other living organisms in the region. Daily exposure to the wastes (landfills) leads to accumulation of harmful substances or microbes in the person's body. A 1990 report by the United States Agency for Toxic Substances and Disease Registry concluded that the general public is not likely to be adversely affected by biomedical waste generated in the traditional healthcare setting. They found, however, that biomedical waste from those settings may pose an injury and exposure risks via occupational contact with medical waste for doctors, nurses, and janitorial, laundry and refuse workers. Further, there are opportunities for the general public to come into contact medical waste, such as needles used illicitly outside healthcare settings, or biomedical waste generated via home health care. 


\section{International Journal of Engineering Applied Sciences and Technology, 2020 \\ Vol. 5, Issue 8, ISSN No. 2455-2143, Pages 229-231 \\ Published Online December 2020 in IJEAST (http://www.ijeast.com)}

\section{LITERATURE REVIEW}

A. Anurag V, Tiwari \& Prashant A. Kadu-"Biomedical waste Management in India- A Review". The Economic development of India in last 2 decades has resulted in Environment Pollution \& Waste Generation in carge Quantity in India. This paper made a attempt to study the classification \& various management pratices by countries. In total generations of BMW 10$15 \%$ is considered infectious. So,the main aim was to create awareness among the Souls. They believed that the key step in reducing the hazards from Biomedical is to Segregate waste at the source. This paper concludes that the Biomedical waste is one of the most hazardous waste generated by human beings. The proper methods of treatment of Biomedical waste need to be developed for health \& Environment Safety.

B. Divya Rao, M.R.Dhakshaini, Ameet Karthukote \& Vidya G.-"Biomedical waste Management : A study on assessment of knowledge, Attitudes \& Pratices among health care Professionals in a tertiary care Teaching Hospitals". The BMW which is generated contains injections \& hazardous Materials \& it is crucial part of the employees to know about the hazards of BMW in the work Environment \& dispose them off safely. This study mainly focues on the gaps in knowledge amongst all the study people. The knowledge in relation to BMWM including the doctors \& Protocols. Attitudes Pratices amongst the different cadres of Staff members were found to be Significant Statistically. This study concludes that the attitudes \& pratices towards BMWM among the study respondents was satisfactory \& are dependent on cadre that they belong too. BMW Management were better among the nurses \& doctors than the other cader of staff.

C. Javid Manzoor and Manoj Sharma-"Impact of Biomedical waste on Environment and human health" The impact of biomedical waste in on water, soil, air quality, the environment and human health. The hospital and nursing homes generate huge amount of biomedical waste in unscientific manner in case of poor management of disposal procedure it causes exposure to health hazards and environmental problems. The issue of biomedical waste identification, handling and disposal so that better management practices can be established. This review concludes that about establishing training programs on proper waste management for a healthcare worker. Research to connect biomedical waste into Energy and other useful products need to be explored. This will be helpful to present environmental contamination and health risk factors.

D. Mohammed Noor Shaida, Sandeep Singh-"Global Biomedical waste management issues \& pratices". Bio- medical waste is a special type of waste which carrier high potential of injection and injury. This study was mainly focused on healthcare management pratices in different hospitals. The data collection was made by various resources \& various procedures opted was analysed \& knew that many were not in apperances with Standard guidelines. This paper concludes that there are few hospitals which follow the Standrad guidlines for a safe disposal of BMW with a proper plan \& this paper also analysed various current Biomedical wastes management \& Some steps for management of healthcare.

\section{METHODOLOGY}

i. Identification of no. of hospitals in the study area.

ii. To know the technical option adopted to treat BMW.

iii. Conducting survey to know the quantity $(\mathrm{kg} / \mathrm{ward})$ of BMW generation at the study area.

iv. Segregated quantity of BMW (RED, YELLOW, BLUE, BLACK, GREEN) identification.

v. Design of Incinerator to treat BMW at source.

\section{CONCLUSION}

The following conclusions are made from the following study:

1. The proper methods of treatment of Biomedical waste need to be developed for health \& Environment Safety.

2. They should also provide health education and training of everyone include in management and handling of biomedical waste.

3. The one should ensure proper identification, segregation at the source of generation, collection in prescribed colored containers, safe transportation, appropriate treatment and environmentally sound disposal of Bio medical waste.

4. There are few hospitals which follow the Standrad guidlines for a safe disposal of BMW with a proper plan \& also should analyse various current Biomedical wastes management \& Some steps for management of healthcare.

\section{REFERENCE}

1) Amrita Singha , Jaspal Singha and A.P. Singha , Rajendra Singhb, 2014, "BIOMEDICAL WASTE MANAGEMENT AND THEIR POSSIBLE HEALTH RISKS WITH CONTROLLING MEASURES IN BAREILLY CITY, UP, INDIA" Octa Journal of Environmental Research Oct - Dec., 2014 International Peer-Reviewed Journa.

2) Anurag V.and Prashanth , 2013, "Biomedical Waste Management Practice in India" International Journal 
of Current Engineering and Techonology ISSN 22774106.

3) Devirajeshwari V , 2016, "Biomedical waste and its management", Journal of chemical and pharmaceutical research.

4) Divya Rao, M.r.Dhakshayini, Ameet Kurthukoli and Vidya G, September 2018 "Biomedical Waste Management: A study on Assessment of Knowledge, Attitude and Practices among Health Care Proffesionals in a Tertiary Care Teaching Hospital", Biomedical and Pharmacology Journal.

5) Javid Manzoor and Manoj Sharma, 2019, “ Impact of Biomedical Waste on Environmental and Human Health", Environmental Claims Journal,

6) Mohammed Noor Shaida , Sandeep Singla. 2019, ISSN:2278-3075,Vol-8 "Global Biomedical Waste Management Issues and Practices". International Journal Innovative Technology and Exploring Engineering.

7) Priya Datta, Gursimran Kaur Mohi, Jagdish Chander, 2016, "Biomedical waste management in India: Critical appraisal", DOI: 10.4103/JLP.JLP_89_17, Department of Microbiology, Government Medical College Hospital, Chandigarh, India.

8) Renju Rajan, Delvin T. Robin*, Vandanarani M, 2017, "Biomedical waste management in Ayurveda hospitals e current practices and future prospective". Journal of Ayurveda and Integrative Medicine

9) Sandip Chakraborty, Belamaranahally Veeregowda, Leena Gowda , 2013, "Biomedical Waste Management", ISSN: 2307-8316, Animal Resources Development Department.

10) $\mathrm{S}$ Manasi $\mathrm{K}, \mathrm{S}$ Umamani, $\mathrm{N}$ Latha, 2014, "BIOMEDICAL WASTE MANAGEMENT: ISSUES AND CONCERNS - A WARD-LEVEL STUDY OF BANGALORE CITY", The Institute for Social and Economic Change, Bangalore

11) Sunil Jayant Kulkarn, 2020, "Biomedical waste scenario in India - regulations, initiatives and awareness", Chemical Engineering Department, Gharda Institute of Technology, Lavel, India. 